\title{
KIRGIZ BELGESEL SINEMASINDA PROPAGANDA
}

\author{
Arș. Gör. Regina CAMANKULOVA ${ }^{1}$
}

\begin{abstract}
ÖZET
$\mathrm{Bu}$ çalışmada, temeli Sovyetler Birliğine ait olan Kırgız belgesel-sinema gelişimi dönemsel bakış açısıyla geniş bir şekilde incelenmiştir. Propaganda kavramının ortaya çıkışı ve farklı ülkeler ve kitle iletişim araçları tarafından kullanılması ile ilgili araştırma yapılmıştır. Kırgız belgesel sinemasının öncüllerinden biri olan yönetmen Tölömüş Okeyev'in "Boom" adlı belgesel yapımı ele alınarak filmdeki propaganda varlığı tarihsel açıdan incelenmiş ve ortaya konulmuştur. $\mathrm{Bu}$ filmde tarihi dönem olarak 1943 yılındaki Sovyet Kırgızistan'ındaki Kant-Rıbaçye şehirlerarasındaki demiryolu inşaatı konu olarak alınmıştır. Sonuç olarak da tarihsel eleştiri açısından propagandanın varlığı ortaya koyulmuştur.
\end{abstract}

Anahtar Kelimeler: Belgesel sinema, propaganda, Kırgızistan.

\footnotetext{
${ }^{1}$ Kırgızistan Türkiye Manas Üniversitesi, İletişim Fakültesi, regina.jamankulova@ gmail.com
} 


\title{
PROPAGANDA IN KYRGYZ DOCUMENTARY FILMS
}

\begin{abstract}
In this thesisthe research is made about the Kyrgyz documentary film development which belongs to Soviet Unionfrom the historical point of view. The research is based on the introduction of propaganda concept and use of it by different states and mass media. In this study criticism method is used in Kyrgyz documentary film propaganda. One of the leading directors of Kyrgyz documentary film Tolomush Okeyev whose "Boom" documentary is used to find existence and emergence of propaganda through historical perspective. In this film historical period of 1943 when in Kyrgyz Soviet the construction of railways between Kant- Ribachye cities is taken as a subject. In conclusion, propaganda is found from the historical critique.
\end{abstract}

Keywords: Documentary film, propaganda, Kyrgyzstan. 


\section{GíRiş}

Amerika'nın 1963'den 1973'e kadar yöneten cumhurbaşkanı Richard. Nixon bir konuşma sırasında propaganda ve bilgiye yatırılmış 1 dolar, silah sisteminin oluşturulmasına yatırılan 10 dolara göre daha değerli olduğunu söylemişti. Çünkü ona göre bilgi her yerde ve her saat başı kullanılmaktadır, ama silahın ne zaman kullanılacağı belli değildir.

Günümüzde sanayi toplumundan bilgi toplumuna geçerken propagandanın hayatımızdaki payı gün geçtikçe artacaktır. Bunun en önemli sebeplerinden birisi bizim kullandığımız bilgi ölçüsünün aniden artı̧ göstermesidir. Ama bizim bilgiyi işleme ve saklama sistemimizin çalışması biraz zorluk çekmektedir. Çünkü televizyon ekranlarından, radyo programlarından ve gazete makalelerinden bize bilgiler durmadan yağmaktadır. Bu bilgileri değerlendirirken zorlandığımız için iletişimcilerin, siyaset ve kültür adamlarının yorumladığı şekilde kabul etmekteyiz. $\mathrm{Bu}$ faktörlerin hepsi bizim bilincimize etki edecek propagandanın psikolojik etkisinin beslenmesine alan oluşturmaktadır.

Günümüzde iletişim alanında iki önemli araç endüstri şeklinde gelişmiştir: radyo ve sinema. Sinemanın dünyanın her tarafına dağılabilme özelliği- sinemayı günümüzün önemli bir ürünü haline getirdi. Eğlence ve problemlerden uzaklaşarak hoş vakit geçirme olanaklarını sunduğu için çok kısa zamanda seyirci kitlenin vazgeçilmez eğlence kaynağı haline geldi. Buna rağmen, toplumun ihtiyaçlarını ne kadar karşıladığı tartışılır.

İlk sinema gösterisi 28 Aralık 1895 y1lında Lumiere kardeşler tarafindan Paris'te Grand Cafe'de yapıldı. Bu film La Siota istasyonuna gelen treni kaydeden ilk belgeseldi. A.Tarkovsky bu filmin mükemmel olduğunu söyler. Hayatın gerçekliliği ve tekrarlanamazlığı bir mükemmellikti. İlk çekilen filmlerin hepsi birer belge niteliğindedir. Ama kimi zaman eğitim kimi zaman da propaganda amaçlı kullanılmıştır. Sinema görüntülü sahnelerden oluştuğu için düşüncelerimizi etkileme gücüne sahiptir. Bir ülkede sinemanın yaygın olarak kullanımı, politik inançların kabul edilmesi yönünde halkın düşüncesini büyük ölçüde etkileyebilecek bir durumdur. $\mathrm{Bu}$ yüzden sinema, para yatıranın elindeki bir silah olarak kabul edilebilir. Sanatsal kaygıdan çok kendi düşüncelerini sunma ve kabul ettirme peşinde olan ticari yatırımcıların bir aracıdır. Sinema, yaşamımızı gözlerimizin önüne seren bir araçtır. Bir eğlence filminin, modern toplumda bir yer doldurma değeri yoktur fakat izleyicinin toplumsal ve uygarlık bilincinin oluşturulmasında onun işlevi henüz son bulmamıştır. 
Belgesel sinema, toplumun sorunlarıyla ilgilenmeli ve gerçekleri olduğu gibi yansıtmalıdır. İyi bir gözlemleme sonucuyla elde edilen bilgilerin gerçekleri ortaya konulmalidir.

\section{AMAÇ VE YÖNTEM}

$\mathrm{Bu}$ çalışma Kırgız belgesel sinemasının propaganda amaçlı kullanılmasının değerlendirilmesi yapılacaktır. $\mathrm{Bu}$ amaçla cevaplandırılacak sorular şunlardır. 1 . Kırgız belgesel sinemasının filmleri hangileridir? Bu belgesel filmlerin içerik ve konuları nelerdir? 2. Kırgız belgesel sinemasının propaganda amaçlı kullanıldı mı? Eğer kullanıldıysa neyin ve kimin propagandasını yaptı?

Bu çalışmanın Kırgız belgesel sinemasını güncelleştirip, üzerinde düşünce ve tartışma olanakları yaratacağı kanısındayım. Bu çalışmaya benzer yeni araştırmalar yapılarak Kırgız belgesel sinemasının derin bir analizinin yapılması için bir ortam sağlayacağı umulmaktadır.

Çalışmanın problem cümlesini oluşturan Kırgız belsegesel sinemasında propaganda yöntemleri insanları yönlendirmek için hangi koşullarda nasıl kullanıldığı araştırılacaktır.

Varsayım: Sovyet belgeseli komünist rejimini devlet düzeyinde propaganda yapmıştır. Kırgızistan’ın film stüdyosu 1942 yılında kurulmuştur. Bu yıllarda Kırgızistan Sovyetler Birliğinin bir cumhuriyeti olduğu için Kırgız belgesel sineması komünist rejimin propagandasını yaptı demektir.

Diğer varsayım: Propaganda açısından en önemli işlevi ise yönetimi kolaylaştırmak olarak vurgulanabilir. Yöneticiler efsanelerden güç alarak, ona dayanarak, ondan güç ve yetki alarak toplumu yönetebilirler.

\section{Propaganda ve propaganda amaçlı belgesel filmler}

Son yıllarda propaganda anlamı üzerinde yapılan araştırmalar propaganda terimini olumsuz anlamından sıyırarak eski anlamına kavuşturmaya çalışmaktadırlar.

Erol Mutlu'ya göre: Propaganda örgütlü inandırma etkinliği; çeşitli inandırıcı araçlarla fikirlerin ve değerlerin yayılmasıdır.(Mutlu, 95, 286)

Yukarıdaki tanımlardan yola çıkılırsa propaganda, insan tutumlarını ve davranışlarını kontrol etme, etkileme, değiştirmek için iletişim araçlarına başvurur. 
Oxford Sözlüğ'ü ise "propaganda" kelimesini, "bir fikre veya harekete taraftar kazandırmak amacı ile düzenlenen programların bütünü’nü olarak nitelendiriyor. Propaganda kelimesi, Latincede "propagare" kökünden gelmektedir. $\mathrm{Bu}$, yeni fidanlar elde etmek üzere toprağa ekmek” anlamındadır. . (Brown,2000:19)

Propagandanın çeşitli amaçları olabilir. Mesela: ulusal propagandanın amacı ülkeyi iyi tanıtmaya yöneliktir. Siyasal partilerin amacı ise oy toplayarak iktidara gelmektir. Kimi güçler gelenekçi propaganda ile tutucu kesimleri desteklerken, kimileri ise yeni bir düzen için devrimci propaganda yürütür. Propaganda bir süreç olduğu için amacına varana kadar sürer. Fakat bazı propagandalar amaçları gereği süreklidir. Buna bir ülkenin uluslar arası propagandası ya da siyasi partinin propagandası örnek gösterilebilir. (Brown,2000:9)

Sinema yoluyla yapılan propaganda, devingen görüntü işin içine girdiği için daha etkili olabilmektedir. Birçok ideoloji sinemayı propaganda aracı olarak kullanmayı denemiştir. Propaganda sinemasını en iyi yorumlayanlar totaliter rejimler olmuştur. Bunların başında Sovyet Sosyalist Cumhuriyetler Birliği ve Nazi Almanya'sıdır. Nazi Almanya'sında propaganda bakanlığı bile kurulmuş, Joseph Paul bu işle görevlendirilmiştir.

Birçok ülkede propaganda rolüne özel ilgi gösterilmişti. Gobbels kendi Potemkin Zırhlısı yaratmaya çağırmıştı. Leni Riefenstahl'ın Iradenin Zaferi ve Olimpiya filmleri propaganda sinemasının en iyi örnekleridir. Iradenin Zaferi'nin konusu Nurnberg'deki Alman sosyalist partisinin VI. nci toplantısinın film raporuydu. Iradenin Zaferi filminin esası Hitleri, Nazizmi yücelterek karizmatik liderin etrafında halkın birleşmesiydi.

Sovyet Sineması 27 Ağustos 1919'da Lenin'in sinema endüstrisini devletleştirmesiyle kurulmuştur. Bu tarihe kadar on yıllık bir geçmişi olan Rus Sineması bir varlık gösterebilmiş değildir. Dünyada devlet tarafından kurulan ilk sinema okulu olan Gosudarstvenaya Shkola Kinematografii ile birlikte ilk günden başlanarak sinemanın propagandacı bir işlev yüklenmesi ilke olarak benimsenmiştir. Büyük çoğunluğu okuma yazma bilmeyen halkın aydınlatılmasında sinemadan yararlanılması tasarlanmıştır

Potemkin Zırhlısı (Bronenosets Potyomkin, 1925) Sergey Eisenstein'a 27 yaşında ün getiren, sinemanın başyapıtlarından biri sayılan filmidir. 1952 Belçika Film ve Güzel Sanatlar Festivali'nde yeryüzünün yüzü aşkın en ünlü sinema adamının yaptığı seçiminde Potemkin Zırhlısı tüm dönemlerin en iyi sinema yapıtı olarak seçilmiştir. Bu filmde de Ekim'de olduğu gibi çarpıcı kurgu kullanılmıştı. Kurguyla cansız nesneler bile devinim kazanmaktaydı. Sinemada ilk kez filmin 
kahramanı olarak, oyuncunun yerine yığını kullanıldı. Çar'a karşı gemideki denizcilerin ayaklanmasını anlatmıştı.

Dziga Vertov'un etkisiyle Rus devriminden sonra propaganda amaçlı tarihi filmler, yeniden düzenleme yöntemiyle belgesel filmler içinde yeni bir tür oluşturdu. Devrimden sonra eksik film stoku ve araç-gereçle çalışmak zorunda kalan belgeselciler özellikle kurgu alanında yeni yöntemler bularak bu türü geliştirdiler.(Öngören, 2003:73)

Dziga Vertov insanların ruhu ve psikolojisini öğrenmesi onun kitle izleyicilerini etkilemeye yönelik araçları aramaya yöneltmişti. Vertov'un sinema çalışmaları ilk devrimden sonraki yeni arayış ve devrim manifestoları yıllara denk gelir. Onların içinden Vertov'un manifestoları maksimum radikallik içermekteydi. Kurmaca filmi tamamen reddederek "Potemkin Zirhlısı" gibi belgesele yakın filmi de inkâr etmişti. Vertov film sanatından verinin doğru olmasını talep ederdi. O salt gerçeğin kaydedilmesini sanat olarak kabul etmezdi, devrimin fikirlerini desteklemesini doğru görmüştü. Lenin'in dediği gibi "Film sanatların içinden en önemlisiydi.". Vertov’un "Kinopravda" (Sinema Gerçek) yayınları birer propaganda aracıydı. Vertov, filmlerinde senaryoya ve oyuncu kullanılmasına karşıydı. Yaşamın senaryoya uygun bir biçimde değil, olduğu gibi kaydedilmesini doğru görmekteydi. $\begin{array}{llll}\text { (Dokumentalnoe } & \text { Kino, } & 3 & \text { May1s, }\end{array}$ http://www.krugosvet.ru/articles/123/1012393/1012393a8.htm)

\section{Kırgız Belgesel Sinemasının Tarihi}

1917 yılına kadar, Kırgızistan'da film üretimi yoktu. Orta Asya halkın hayatını aydınlatmak için "Vostokkino” kurumu kuruldu. Kırgızistan hakkında ilk filmler 1920 yılların sonlarına doğru çekilmeye başladı. Kırgız halkın hayatını beyaz perdeye aktarmak için Moskova'dan kameramanlar gelmeye başladı. Sovyet coğrafik filmin kurucusu olan V. Şneyderov kendisi senaryoları yazarak Podnojiye Smerti (Ölüm Tabanında, 1928) ve Na Vysote 4500 Metrov (4500 m Yükseklikte, 1931) adlı gezi filmlerini çekti. Bu filmler Kırgız halkını SSCB izleyicilerine kendine has ulusal kültür ve hayatıyla göstermeyi başardı. İlk Frunze film stüdyosu 1942'de kuruldu. Burada kameraman M. Kalsanov ve yönetmen D.Erdman ile birlikte Rus grubu çalıştı. İlk belgesellerin çoğunun konusu II. Dünya Savaş sırasındaki günlük hayatın betimlenmesi halindedir. 1943'de ise Sovetskaya Kirgiziya film dergisi yayımlanmaya başlıyor. Film derginin yayınlarının amacı vatanseverlik duyguları uyandırmak ve savaş hakkında bilgileri vermektir. Savaşın sonuna kadar Sovetskaya Kirgiziya film dergisinin sayıs1 100 ulaştı. 
1940 yılın sonuna doğru Kırgız belgeselcilerin grubu oluşturuldu. Belgeselcilerin zor şartlarda yaptığı çalışmaların katkısıyla film üretiminin sayısı genişledi. İlk belgesellerin kitlesel yayımına olanaklar sağlandı, onların çoğunun konusunu ulusal tarım ve ziraat alanlarındaki başarıları oluşturmaktaydı. 1950 yılların ortalarında Kırgız belgesel yapımında genç yönetmenler A.Tokarev, İ.Kokeev, L. Turusbekova, F. Mamuralieva, ses yönetmenleri T. Okeyev (gelecekteki yönetmen), kameramanlar K. Kıdıraliev, M. Turatbekov ve başkalar çalışmaya başlar. Onlar eğitimi Moskova, Leningrad ve Frunze'de (Günümüzdeki başkent Bişkek) görmüştür. Bu yönetmenler günlük hayatı betimlerken geleneksel anlayışlardan kaçındılar. Bu onları sadece bilgi vermekten değil, daha çok insanların karakterlerini ve onları kuşatan sosyal çevresini derinlemesine incelemek için yöntemler aramasına olanak tanıdı. Bu durumda filmi seslendirenin rolü sadece filmi seslendirmek değil aynı zamanda mesleğinin de pozisyonunu belli etmek de oluyordu. ( http://www.welcome.kg/ru/kyrgyzstan/culture/ggogg/)

Kırgız belgeselciler komşu memleketlerin yönetmenleri ile birlikte film çekmeyi denediler. Bu tür çalışmalar onlara yeni deneyimler kazandırdı. 1960 yılların başlarında M. Ubukeyev, S. İşenov, G. Bazarov, K. Ömürkoluv ve diğer Kırgız belgeselciler filmin konularını genişletip izleyiciye olan etkisini araştırarak gizli kamera, ses ile görüntüyü aynı anda kullanmaya başladılar. Bu konularla ilgili Y. Gernşteyn'in 1963 yapımlı, Zavodskiye Vstreçi (Fabrika Buluşmaları) filmini örnek olarak gösterilebilir. Bu filmde, bir fabrika hayatını gösterirken ilk defa sesefektleri kullanıldı. Yönetmenler A. Vidugiris ve M. Morgaçev’un Obraşennıe K Solntsu filminde de ses-efektlerini kulland1.

1960 yılların ortalarında çekilen M. Ubukeyev'in Gornie Reki, Akın (Şair), B.Şamşiev'in Manasçı, Çaban, T.Okeyev'in Eto Loşadi (Bu Atlar), Muras (Miras), Bübüsara Beyşenalieva, Hudojnik Chuykov, İ. Gorelik'in Kliatva Gippokrata (Hippokrat Yemini), L. Turusbekova'nın Velikiy Epos filmleri Kırgızistan film yapımcılarına uluslar arası ün kazandırdı. A. Vidugiris'ın Narınskiy Dnevnik (Narın Gümlüğü, 1971) ve V God Nespokoynogo Solntsa (1977), filmleri özel bir yere sahiptir. Bu film Toktogul Hidraelektrik Santralın kuruluşunda önemli emekleri filme çeker burada yapımcı sadece gözlemci değil kendisi de aktif katılımcı olur. Kırgız Yönetmenler gerçek olguları kaydederken kendi yönetmenlik algılarını kullanmışlardır. Aynı anda gerçeğin kritik analizini de yapmışlardır. Bu tür filmlere K.Yusupjanova'nın Pastuh $i$ Tuman, Tigr Zadral Dvuh Korov Na Jayloo, Ş. Apılov'un Kıyır, K.Abdıkulov'un Jorgo, Puty, Ş. Japarov'un Koçevie Kosmonavta, K.Akmataliev'in Nakil Kitep (Kırgız ansiklopedi yazarları hakkında), K.Kıdıraliev'in Beşik (mimar T. Sadıkov ile ilgili) filmleri gösterilebilir. 
L. Turusbekova'nın 1962 yılında çektiği Velikiy Epos filminden sonra Manas destanının konusu açılır. Velikiy Epos filminde ve buna benzer diğer filmlerde de izleyicilerin Manasçıyı (manas destanını söyleyen destancı) dikkatle izlemeleri çok hayret vericidir. Onlar eski destan kahramanlarının zaferlerini anlatarak, zamanlarda geçmiş ile geleceği bir araya getirmekteydiler. B.Şamşiev’in Manasçı (1965) filminde dünyaya büyük manasçı Sayakbay Karalaev’i tanıtarak, konunun orijinal işlemesine dikkat çekmiştir (Oberhauzen uluslar arası film festivalinde ödül kazanmıştır). 1980'lerin sonlarında Manas'a adanmış filmlerin içeriğinde dönüşüm meydana gelmiştir. Yeniçağın filmleri, destanın ve modern dünyanın birlikte var olmasını yansıtmaktadır. M. Ubukeyev'in Posledniy Manasçı (1989) ve Ş. Apılov'un Kaaba (1992) filmlerinde destancı tek başına ele alınmıştı onu büyük ilgiyle dinleyen dinleyicileri yoktu. E. Abdijaparov'un Menin Pirim Almanbet (1993) filminde Manasçının bütün özelliklerini taşıyıp da manasçı olamayan yetenekli insan gösterilmişti. (http://www.welcome.kg/ru/kyrgyzstan/culture/ggogg/)

SSCB'nin dağılımından sonra toplumsal hayattaki değişiklikler belgesel sinemayı da etkiledi. Bunu yansıtan belgeseller çekildi. Onlar ise E. Abdijaparov'un Ostanovka (1994), Tarançı (1997), Aldey, Algambra (2000), T.Birnazarov'un Ne Plaç, Nosorog (1994), Çertov Most, Jayık, B.Aytkuluyev"in Okno filmleri geçiş zamanlarda insanın zorluklara karşı savaşına adanmıştır.

\section{"Boom" Belgesel Filminin Yönetmeni Tölömüş Okeyev}

Tölömüş Okeyev, 11 Eylül 1935 yılında Kırgızistan’ın Isık-Göl bölgesinin Bökönbay köyünde dünyaya geldi. Çocukluğundan beri sinema meraklısı olan Okeyev, 1953 y1lında Leningrad'daki (Petersburg) Sinema Mühendisleri Enstitüsü'nün Ses Mühendisi Bölümü'nde eğitim görür. 1958'de mezun olduktan sonra Frunze'deki "Kırgıfillm” sinema stüdyosuna gelerek önce ses mühendisi, daha sonra ses operatörü olarak 1963'e kadar çalışır. Sovyet yönetmeni Larissa Şepitko'nun, yazar Cengiz Aytmatov'un Devenin Gözü adlı öyküsünü beyazperdeye uyarlayıp "Kırgızfilm” stüdyosunda çektiği, bol ödüllü Ateş (Znoy, 1963) ve M. Roşal'ın çektiği Kosmonavtlar Caddesi (Ulitsa Kosmonavtov, 1963) filminin ses yönetmenliğini üstlenir. Gene bu stüdyonun yapımı olan, ayrıca hayatında ilk ve tek olarak oynadığı sinema filmi ise, Zor Geçit’tir . (Baygaliyeva, 2003:77)

1964-1966 y1llarında Moskova'da bulunan Devlet Sinema Enstitüsünün (VGIKK) Yüksek Yönetmenlik ve Senaristlik Bölümü’nde yüksek lisans eğitimini görür. Eğitiminin ilk yıllarında, sinema tekniği, üretimi ve müzikten az buçuk anlamasına rağmen resim, edebiyatla ilgili bilgilerinin istediği derecede olmadığı, tiyatrodan hiç anlamadığı ve oyuncularla nasıl çalışması gerektiğini bilmediği; bu 
sebeple de değerlerinden geri kalmamak ve bu konulardaki eksiklerini gidermek için çok çalışır.

\section{"Boom" Belgesel Filminin Analizi}

Filmin ilk karesinde elinde tüfek tutan askerler gözükür arkasından tüfek sesi duyulur. Film başlamadan önce siyah fon üzerinde beyaz yazılar çıkar: "1943 yılında Sovyet halkının Alman Faşistleriyle olan savaşı sırasında Devlet Savunma Komitesi Kant-Rıbaçye demiryolunun inşaatının devam edilmesi ile ilgili karar ald1." "Sovyetskaya Kirgiziya" gazetesinden diye bir yazı gösterildikten sonra bir fotoğraf gösterilir. Fotoğrafta atlar üzerinde askerler ve en öndeki askerlerin elindeki bayrakta "Her şey Cephe İçin ve Her şey Zafer İçin!” yazısı yazılmıştır.

$\mathrm{Bu}$ fotoğraf görüntüsünden sonra 4 tane işçi adam fotoğrafi görünür. Aralarından bir tanesinin eli bezle sarılmış ve boynuna asılmıştı. Fotoğraftan sonra gene siyah fon üzerine yazı çıkacaktır.

"Bu demiryolu doğal şartların zor olmasından ve inşa edilmesinin zorlukları açısından SSCB'de tek demiryolu olacaktır.” SSCB Coğrafi Enstitü uzmanlarının özeti diye yazı gösterildikten sonra dağlar arasında elerinde kürek tutan işçiler çalışma sırasında gösterilir ve fonda olarak tren sesi duyulur. Arkasından hemen sonra Kant-Rıbaçye demiryolunun kahraman işçilerinin anısına yazısı çıkar. Sonra filmin adi $B O O M$ olur.

Trenin içi gösterilir ve uzaktan bir yaşlı adam görünür, adımlarını ileri atarak trenin koridorundan kameraya doğru yürür. Kadın sesi: "Dikkat, dikkat sayın yolcular Kant-Rıbaçye 992'nolu trenin kalkmasına 5 dakika kaldı. Yerlerinize oturmanızı rica ediyoruz. Uğurlamaya gelen arkadaşlarımızın da tren hareket ettikten sonra atlamamasını rica ediyoruz. Hayatınız için tehlikelidir." diye anons eder. Yaşlı adam yaklaşınca yakın çekimle yüzünü görürüz. Yüzü yaşının ilerlediğini açıkça gösterir. Üzerinde yakalı palto ve kafasında şapkası vardır. Yaşlı adam trendeki yerini alır ve tren ilerlemeye başlar. Yakın çekimle trenin ön tarafi gösterilir ve tren yol alır.

Trenin içinde elinde nevresim tutan bir bayan yakın çekimle gösterilir. Yaşlı adama uyuyup uyumayacağını sorar. Yaşlı adam ise paltosunun gösterir ve onun ona yeteceğini söyler.

Doğa manzarası gösterildikten sonra genel çekimle yaşlı adam ve karşısında oturan bir bayan çay içerken gösterilir. Bayan adamın nereye gideceğini ve şehirde kimin evinde kaldığını sorar. 
Kamera yaşlı adama doğru yaklaşır ve adamın yüzünü çok yakından görürüz. Son günlerini yaşadığını ve belki de bu yol üzerinde son yolculuğu olduğunu söyler. İşçilerin olduğu sahneye geçiş yapılır. Sonra yaşlı adamın yüzünü görürüz ve onun da onların arasında olduğunu söyler. Onun ismi Akmat olduğunu, o da bu yolu kurduğunu ve 4 sene Isık Göl'e doğru yürüyerek bu yamaçtan geçtiklerini anlatırken filmde elinde meşalelerle yürüyen işçileri görürüz. Gene yaşlı adamın yüzü profilden yakın çekimle görünür ve yaşlı adam düşüncelidir. Ardından da elindeki aletiyle taşı kırmaya çalışan işçi gösterilir. Daha sonra genel çekimle çalışan işçiler görünür. Taş sesleri ve rüzgârın esmesi duyulur. Yaşlı adam savaş döneminde bütün genç yiğitlerin cephede olduklarını ve işçilerin de kendi cephelerinin olduğunu söyler, bu da yamaçdır onlar için. Aynı zamanda, sadece kürek ve kazma ile çalışmanın çok zor olduğunu anlatır.

Daha güneş çıkmadan işe başladıklarını ve gecenin yarısına kadar elleri nasır tutuncaya kadar çalıştıklarını söyler. Genel çekimle karanlıklar içinde meşalelerle çalışan erkek ve bayan işçiler gösterilir. Soğuk rüzgâr iliklerine kadar girmiş ama onlar bu yolun amacını unutmamışlar. Bu yol üzerinde cepheye et, ekmek, atlar ve her türlü ihtiyaç gönderileceğini bildiklerini söylediğinde yakın çekimle taşlara vuran bayan görünür. Adam yakın çekimle gösterilir ve onların kendi oğul ve torunlarını düşündüklerini ve yenilmemeleri gerektiğini söyler. Rayların üzerinde öne doğru ilerleyen tren gösterilir. Trenin ilerleyişi genel çekimle gösterilir. Tren gösterilirken adam bir efsane anlatır.

Bir zamanlar yamaç Isık-Göl'ü seviyormuş ve gölün onu 1sıtmasını istemiş ama Göl sularını göndermemiş yamaca ve o günden sonra yamaç daha da sertleşmiş. Göl tarafina halkta "Ulan" denilen soğuk rüzgâr esip durmuş ve kimseyi göle geçirmeyeceğine dair yemin etmiş. Sonra adam yakın çekimle gösterilir. Bütün soğuk ve karın onları durduramadığını, onların çocuklarını düşündüklerini anlatır. Çünkü yaşlı adam onların kendi yeminlerinin olduğunu ve o yemini bozmamaları gerektiğini anlatır.

Yerlerdeki karları kürekle temizleyen iki kadınla bir erkek gösterilir. Arkasından genel çekimlerle elinde kazmalarla çalışan işçiler görünür. Böyle bir sahnenin arkasından genel çekimle uzun tahtaları taşıyan işçiler gösterilir. Daha sonra karlı dağların arasında ilerleyen tren görünür. Adam yakın çekimle yemek yerken gösterilir. Sonra genel çekimle dağ yamacındaki yol ve onun biraz yukarısındaki tren yolu yukarıdan gösterilir. Tren yolunun üzerinden tren ilerler ve sesi duyulur. Yaşlı adam artık Isık-Göl'e yolculuk yapmanın ne kadar kolay olduğunu anlatır. Raylar üzerinde ilerleyen tren ve yanındaki paralel yolda da arabalar ve kamyonların görüntüleri genel çekimle gösterilir. 
Yaşlı adam eskiden bu yol üzerinde yolculuk etmek için hayal ettiğini hiç olmazsa çocuklarının yolculuk yapacağına inandığını söyler. Ama artık bu yol üzerinden Moskova'ya kadar ve ondan daha ilerisini yolculuk yapilabileceğinden bahseder. Düşünen yaşlı adamın profili yakın çekimle gösterilir.

Bir patlama sahnesinden görüntüler görünür ve bir işçi elindeki kürekle patlamaya şaşkın bakarken gösterilir. Taşları yerinden oynatmaya çalışan işçiler genel çekimle gösterilir. Büyük bir taş parçası bir adamın yakınındaki yere çakılır. Büyük taşı urganla bir grup halinde çekmeye çalışan işçiler görünür. Erkek işçilerin arasında çalışan işçi kadınlar da görünür. Bir kadınla bir erkek taş dolu sedyeleri taşırlar.

Taştan daha sert ancak demir olabileceğini söyler yaşlı adam. Ama demir insanın elinde olursa güç kazanır der. İleri doğru ilerleyen tren yukarıdan gösterilir trenin sesi duyulur. İşçiler yerdeki taşları parçalarken görürüz ve adam bu gücü onların nereden aldıklarını kendi kendine sorar. Çünkü çalışanlarının çoğunu cepheye alınmayanlar elinde tüfek tutamayanlardan oluşturulduğunu söyler. Yakın çekimle taşı dövmeye çalışan genç bayan görünür. Gene genel çekimlerle kumları küreklemeye çalışan işçiler görünür. Adam savaşın onları daha güçlendirdiğini söyler çünkü çalışanların çoğunun güçsüz ve elinde tüfek tutamayanlardan oluştuğunu, ata babalarının ve Manas'ın ruhlarını uyandırdığını söyler.

İki bayanın büyük taş dolu sedyeleri taşıyarak yere döktüğü gösterilir. Yaşlı adam gözlerindeki yaşları silerken yakın çekimle gösterilir. Sonra tren gösterilir ve adam 1945 yılında zafer haberi aldıklarını söyler. Bu günü ne kadar çok beklediklerini, herkes çalışma aletlerini bırakmış, birbirilerine sarıldıklarını, güldüklerini ve ağladıklarını anlatır. Yaşlı adam sevinçten insanlar daha çok ağladığını söyler.

Savaştan dönenler de artık bu demir yolunun kurulmasına yardım ettiklerini anlatırken genel çekimle çalışan işçiler görünür. Yamacın yeminine sadık kaldığını söyler. İşçilerin taşları alıp aşağıya doğru firlatmaya çalışırken görürüz. Birkaç kişi büyük kaya parçalarını birbirine destek vererek aşağıya doğru kaydırırlar. Ama o taşlar çalışan başka işçilerin başlarına ve başka yerlerine zarar verir. Sonra tren mezarların olduğu yerden geçer. Adamda mezarda yatan arkadaşları Teşebay ve Joldoş'a ve diğer hemşerilerine selam verir. Onların bu yolu göremediklerini ve Boom üzerindeki zaferinin göremediklerini söyler. Yüzlerini Isık-Göl'de yıkayamadıklarını söyler.

İlk defa Mayıs aylarında Kant-Rıbaçye yolundan ilk tren geçtiğinde onların çok sevindiklerini ve rayları öptüklerini anlatırken tren gösterilir ve tren üzerindeki 
Lenin'in resmi olan bayrağın dalgalandığını çok yakından gösterilir. Genel çekimle göl ve üzerinde uçuşan martılar görünür.

Tren insanların kalabalık oluşturduğu yere gelir. Orda bütün işçiler toplanmıştı. Yaşlı adam ilk defa bütün işçileri bir anda gördüğünü ve onların bu kadar çok olduklarını bilmediğini anlatır. Bu arada açık havada tören sahneleri gösterilir. Mutlu yüzler, el sıkışmaları görürüz. Onlara ödüllendirdiklerini ve kahraman dediklerini söyler. Yaşlı adam kendisinin Isık-Göl'de Törtköl köyünde doğup burada büyüdügünü söyler ve onun için Isık-Göl ile kavuşmanın ayrı bir sevinç verdiğini söyler. Bunları söylerken gölün görüntüleri gösterilir ve yazılar çıkarak film sona erer.

\section{Kuramsal Açıdan Boom Belgesel Filminde Propaganda Unsuru}

Jean Marie DOMENACH tarafından ortaya atılan propagandanın beş kuralı bağlamında Boom belgesel filmini değerlendirilmesi yapıldığında aşağıdaki bilgilere ulaşılabilir.

Tek Düşmanlık ve Yalınlık Kuralı Açısından

Propaganda, konuyu herkes tarafından kolaylıkla anlaşılabilir sade ve yalın duruma getirmelidir. Boom belgesel filminin konusu itibarıyla ele alındığında, konu, olabildiğince yalın bir şekilde işlemiştir. Mesajlar herkesin kolaylıkla anlayabileceği tarzda sunulmaktadır. Filmin asıl konusu işçilerin kahramanlıklarını anlatmaktır. Filmin bütününde bu konu işlenmektedir.

Propaganda tek bir hedefe odaklandığında daha başarılı olur. Propagandacı, iletmek istediği mesajları tek bir düşman belirleyip onun üzerine yüklenmektedir. $\mathrm{Bu}$ filmde belirlenen düşman da Nazi Almanya'sıdır. Onunla olan mücadele demiryolu ile bağdaştırılarak verilmiştir.

Yamacı yenmek Almanya'yı yenmek ile aynı manadadır. Çünkü bu demiryolu savaş sırasında çok gerekliydi. Her türlü ihtiyaç cepheye bu demiryolu üzerinden gönderilecekti. Ne pahasına olursa olsun bu demiryolu inşaatını devam ettirmek lazımdı. Bu yüzden yaşlı adam kendilerine yemin verdiklerini ve o yemini tutacaklarını söyler.

\section{Büyütme ve Bozma Kuralı Açısından}

Propagandacı, kendi işine gele mesajlara daha aşırı önem vererek gerektiği zaman abartarak ve değiştirerek sunar. 
Boom belgesel filminin bütününe bakıldığında, filmde iletilen mesajların tek taraflı şekilde işlendiği görülmektedir. $\mathrm{Bu}$ belgesel filmde demiryolu inşaatı sırasındaki yaşanan zorluklara değenilmemektedir. Sadece demiryolunun öneminden bahsediliyor. Aslında çalışma şartlarının ağırlılarından dolayı ölenlerin sayısı çoktu. $\mathrm{Bu}$ demiryolu ilkel yöntemler ile inşa edildiği için işçiler zorluk çekmişlerdi. Filmde yaşlı adam da bundan bahsediyor, çünkü sadece cepheye gidemeyenler çalışırlar. Filmin çoğu karesinde çalışan bayanları görmek mümkündür.

\section{Tekrar Kuralı Açısından}

İyi bir propaganda için gerekli olanlardan birisi de verilmek istenen mesajların olabildiğince fazla şekilde ve durmaksızın tekrar edilmesidir. Hedef kitle tarafından kabul edilmesi için bıkıp usanmadan tekrar edilmelidir.

Boom belgesel filminin içerisinde de verilmek istenen mesajlar devamlı tekrar edilerek sunulmuştur. Film boyunca bu yolun ne kadar zorluklarla kurulduğu çeşitli şekilde dile getirilmektedir. Hep işçilerin çalıştığı sahneler birbirinin arkasını izlemektedir.

Daha güneş çıkmadan işe başladıklarını ve gecenin yarısına kadar elleri nasır tutuncaya kadar çalıştıklarını söyler. Soğuk rüzgâr iliklerine kadar girmiş ama onlar bu yolun amacını unutmamışlar. Bu yol üzerinde cepheye et, ekmek, atlar ve her türlü ihtiyaç gönderileceğini bildiklerini söylediğinde yakın çekimle taşlara vuran bayan görünür. Adam yakın çekimle gösterilir ve onların kendi oğul ve torunlarını düşündüklerini ve yenilmemeleri gerektiğini söyler. Bütün soğuk ve karın onları durduramadığını, onların çocuklarını düşündüklerini anlatır. Çünkü yaşlı adam onların kendi yeminlerinin olduğunu ve o yemini bozmamaları gerektiğini anlatır. Yaşlı adam eskiden bu yol üzerinde yolculuk etmek için hayal ettiğini hiç olmazsa çocuklarının yolculuk yapacağına inandığını söyler. İşçiler yerdeki taşları parçalarken görürüz ve adam bu gücü onların nereden aldıklarını kendi kendine sorar. Çünkü çalışanlarının çoğunu cepheye alınmayanlar elinde tüfek tutamayanlardan oluşturulduğunu söyler. Yakın çekimle taşı dövmeye çalışan genç bayan görünür. Gene genel çekimlerle kumları küreklemeye çalışan işçiler görünür. Adam savaşın onları daha güçlendirdiğini söyler çünkü çalışanların çoğunun güçsüz ve elinde tüfek tutamayanlardan oluştuğunu, ata babalarının ve Manas'ın ruhlarını uyandırdığını söyler.

\section{Aşılama Kuralı Açısından}

Propagandacı başarılı olmak istiyorsa yeni bir konuyu anlatmaya girişmez. Önceden var olan bir zemin üzerinde çalışmalıdır. Bir kalabalığın karşısında 
konuşulurken ona ters düşülemeyeceği, kendi düşüncelerine yöneltmeden önce onun fikirleri yönünde yer almakla işe başlamak gerektiği unutulmaması gereken bir ilkedir.

Filmde SSCB'nin düşmanı olan Almanya'ya karşı savaş sırasında askerlere gönderilecek her türlü ihtiyaç için bu demiryolu inşaatı bir şarttı. Çalışan işçilerin hepsi bunun farkındaydı. Yani yeni bir düşman ya da fikir ortaya atılmadı sadece var olan düşmana karşı kin daha da şiddetlendirildi.

\section{Birlik ve Bulaşma Kuralı Açısından}

İnsanlar, genellikle bulundukları topluluğa ters düşecek fikirleri söylemekten kaçınırlar.

Filmde de izleyicilere ortak bir çalışma bilincini örnekleri verilmeye çalışılmıştır. Savaşa katılamayan herkes bu yolu kurmaya yardım etmiştir. Çalışanların içinde yaşlı, genç bayanlar da vardı. Bu görüntülerin hepsi birlik beraberlik havası içinde verilmiştir. Bayanlar, erkeklerle birlikte aynı işi yapıyorlardı. Savaş bitikten sonra savaştan gelenlerle birlikte bu yolun inşaatı tamamlandı. Birlik ve beraberlik havası film boyunca yaratılmıştır.

Tren insanların kalabalık oluşturduğu yere gelir. Orda bütün işçiler toplanmıştı. Yaşlı adam ilk defa bütün işçileri bir anda gördüğünü ve onların bu kadar çok olduklarını bilmediğini anlatır. $\mathrm{Bu}$ arada açık havada tören sahneleri gösterilir. Mutlu yüzler, el sıkışmaları görürüz. Onlara ödüllendirdiklerini ve kahraman dediklerini söyler.

“Boom” Belgesel Filminin Tarihsel Eleştirisi

"Hüküm. "Kant-Rıbaçye demiryolunun inşaatı ile ilgili karar” SSCB Devlet Savunma Komitesi tarafindan 3 Eylül 1943 yılında ( № 4027) kabul edildi."(Turdakun, USUBALIYEV. “İftiracılara Cevap", 23 Mart 2008. http://www.analitika.org/article.php?story=20071002122827495\&mode=print)

No 4027. 3 Eylül Evrak 149, s:10-12

Hüküm. Kırgız SSB' inde Kant-Rıbaçye demiryolunun inşaatı ile ilgili karar alınır. " ( B.A. Tomman. “ SSSC'nin Devlet Savunma Komite'sinin (1941-1945 yy.) Gizli Evraklarının Listesi." 4 Mart 2008. http://www.rusarchives.ru/secret/943.shtml ) 
"Jozef Şmuleviç (BRZOZOWICZ, doğum tarihi 1920, Yahudi asıllı) ve onun erkek kardeşi Abram Şmuleviç BRZOZOWICZ, (doğum tarihi, 1912) 1939 yılı Eylülde Hitler ordusundan kurtulmak amacıyla Varşova'dan kaçarak, Sovyet toprağındaki işgal edilen bölgelerden Belostok şehrine doğru yol aldılar. Sovyetler toprağına giriş yasaklandığından dolayı binlerce mülteci nötr topraklarda toplanmıştı. En sonunda mültecileri Belovostok şehrinin içine alarak hepsini bir araya topladılar. Daha sonra onları kendi tarafina çekerek çeşitli yerlere iş için çağırmaya başladılar. Josef Şmuleviç Orlovka bölgesinin Klintsı şehrine geçerek, Orta Asya'ya Almatı şehrine sonra Frunze (Günümüzdeki başken) şehrine gider. 1941 yılı işçi ordusuna çağırılarak daha sonra Kant-Rıbaçye demir yolunun inşaatının askeri inşaat bölümüne sevk edilir. Çalışma şartları zordu, her zaman karnı tam doymuyordu. İşçilere çay verilince en yakın Kırgız köylerine gidip unla değiştiriyorlardı. Geceleri ise tarladaki şeker pancarlarıyla karnını doyurmak için kazıp yiyorlardı." (B.S.Birger, "Josef Şmuleviç BRZOZOWICZ'in İletisi" (16 Nisan1991) 5 Mart 2007. http://www.memorial.krsk.ru/svidet/mbrzoz.htm)

Toprak işleri mekanikleştirerek kazma işleri için her çeşit makineler icat edildi. II. Dünya Savaşı sırasında yeni demir yollarını acil bir şekilde kurmak zorunda kaldılar. Saratova'dan Staliningrad'a kadar yol kurulurken istasyonunun arkasındaki büyük tepe engel oldu. Tepenin içinden derin bir buçuk kilometre uzunluğunda tünel kazılması gerekiyordu. Yüz bin küp metre toprağı dışarı çıkarmak için yüz binlerce işçi, onlarca platform, ekskavatörleri ve sekiz aylık süreç lazımdı. İşte o zaman patlatıcı işçilerini çağırma fikri doğar. Mühendislerin, kazı işlerini yapan işçilerinin kuyu kazma işleri 1 aylık zaman aldı. Bir gün içinde kuyulara 300 ton patlayıcı madde yerleştirerek gece elektriği yaktılar. Patlama işlemi gerçekleştikten sonra düz geniş çukur ek işlem yapmadan rayları yerleştirebildiler. Böylece inşaatta "Jeldorvzrıvprom" (Demiryolu Kurulması İçin Patlatma İşleri) ortaya çıktı. Küçük kurum kendini kanıtladı.

Kant-Rıbaçye demiryolunun inşaatını patlamasız hayal etmek imkânsızdır. Frunze'den (Günümüzde Bişkek) Kant istasyonuna kadar uzanan yol dağlara dayanıyordu, Kırgızistan'ın başkentini Isık-Göl bölgesini demiryoluyla birleştirmeye engel oluyordu. Dağlar arasında sadece aşağısından Çüy nehri akan yamacı aşarak geçilir. Yamacın üzerinde raf halinde olan yolun yapılması gerekiyordu. Patlatma işini yapan iş̧̧iler dağcılar gibi kayalara tırmandılar. Dă̆ çıkıntılarına kendilerini iplerlerle bağlayarak çıkıyorlardı. Böylece onlar 16 kilometrelik bu yol üzerinde patlatıcı maddeleri yerleştirdiler.

"Boom" yamacında otuza yakın patlama gerçekleşmişti. Yamacın sağ tarafından sert kayanın milyon küp metresi yıkıldıktan sonra demiryolu için meydan oluşmuştu. "Jeldorvzrıvprom" pratikte kitlesel patlamaların yardımı neticesinde 
sadece çukur değil toprak yığınını yapılabileceğini kanıtladı. Patlatıcıların kurumu birkaç yıllık çalışma sırasında kendi yöntemlerini geliştirdiler. Tepenin engel olduğu yolu 500 metreye kadar uzatabiliyorlardı. Patlatma yapmasaydılar büyük çabalar gerektirirdi, ekskavatör ve bir sürü mekanizma gerekecekti. İnşaatçılar patlatma yöntemine başvurdular. Onlar 45 kuyuya 175 ton tol ve ammonit yerleştirirler. Çok iyi yerleştirildikleri için patlama sonucu sadece yerin düzeltilme işlemi kalmıştı. ("Jeleznniye Dorogii Rosii" 7 Mart http://www.1520mm.ru/history/rall50/10.htm )

Boom belgesel filmin tarihsel eleştirisini yapmak için Kant-Rıbaçye demiryolunun kurulmasını anlatan bu filmde geçmiş ile geleceğin bağlantısını ortaya koymak adına öncelikle bu demir yolu inşaatı ile ilgili yazılı kaynakları vermek gerekli görülmüştür.

Boom belgesel filmi de 1943 yılında başlatılan Kant-Rıbaçye demiryolu kurulma esnasındaki zorlukları anlatmaktadır ama onların bu zorlukların hepsini nasıl başardıklarını bir yaşlı işçinin ağzından anlatmaktadır.

Boom belgesel filminde iki şehri Kant-Rıbaçye arasındaki demiryolu inşaatını gösteriyor. Boom belgeselinde anlatılan Kant-Rıbaçye demiryolunun inşaatının önemi çok büyüktür. Çünkü bu demiryolunun inşaatı ile ilgili karar 3 Eylül 1943 yılında Devlet Savunma Komitesi tarafından kabul edildi. Kant-Rıbaçye demiryolunun kuruluşu Kırgızistan ile Merkezi Moskova arasındaki ilişkiyi daha da yakınlaştırmaktadır. Filmde de belirtildiği gibi Kırgızistan'ın başkenti Bişkek'ten ve Isık-Göl bölgesi arasındaki ulaşımı sağlayan demiryolu Moskova'ya kadar devam etmektedir. Bu demiryolu iki ülke arasındaki mesafeyi kısaltmaktadır. Siyasi açıdan bakıldığında Kırgızistan’ı Moskova'ya daha da bağlı kılmaktadır. Bu demir yolu hala kullanılmaktadır.

Ana konusu demiryolunun inşaatı olan Boom belgesel filminin içeriği, kullanılan semboller, anlatımı göz önüne alınınca propaganda öğeleri taşıdığı söylenebilir. Çekim planları, kamera açıları ile desteklenerek oluşturulan anlatım dili propaganda özellikleri bakımından güçlendirilmiştir.

Filmin ilk karelerinde 1943 yılında Sovyet halkının Alman Faşistleriyle olan savaşı sırasında Devlet Savunma Komitesi Kant-Rıbaçye demiryolu inşaatının devam edilmesi ile ilgili karar alınd1. "Sovyetskaya Kirgiziya" gazetesinden diye bir yazı gösterilir.

1943 yılında Almanlarla olan savaş kızışınca bile bu demiryolu inşaatının durdurulmaması bu demiryolunun önemini vurgulamaktadır. $\mathrm{Bu}$ demiryolu 
üzerinden cepheye yemek, giysi, at, silah ve her türlü ihtiyaç gönderilecekti. KantRıbaçye demiryolunun inşaatı 4 sene sürer. Çalışma şartları çok zordur. Çünkü neredeyse çıplak ellerle çalışılır. Josef Şmuleviç’in günlügüunde işçilerin çoğu zaman aç çalıştıklarını anlatıyor. Fakat filmde işçilerin aç kaldıklarından söz edilmiyor. Sadece çalışma sırasında soğuktan ve zor şartlardan söz ediliyor. Filmde işçilerin çalışma şartlarına az odaklanılıyor. Sadece filmin ilk başlarında yaşlı adam daha güneş çıkmadan işe başladıklarını ve gecenin yarısına kadar ellerinin parmaklarının su toplayıncaya kadar çalıştıklarını anlatır. Boom'da kullanılan patlama yöntemlerinden bahsedilmez oysaki patlama olmadan bu demiryolunun inşaatının gerçekleşmesi çok zordu. Sadece filmde çalışma sırasında bir tane patlama sahnesi gösterilir. Bu belgesel filminde çalışma yöntemlerinden daha çok insanların nasıl bir ruhla çalıştığını anlatılmaktadır. İnsanları kahramanlaştırarak gelecek nesillere aktarmaktadır. Bu bağlamda Boom belgesel filminin duygusal boyutu ön plana çıkmaktadır. Yaşlı adamın hikâyesini anlatırken gözlerinin yaşarması, demiryolunun ilk açılışında insanların yüzündeki sevinç, filmin “doku-drama” şeklinde çekildiğini kanitlamaktadir.

Boom belgesel filmi II. Dünya Savaşı sırasındaki zamanı yansıtır. Burada direk olarak İkinci Dünya Savaşı ile bağlantılıdır. Sovyetler Birliği Almanlara karşı savaşı kaybetmektedir ve Nazi Almanya'nın askerleri neredeyse Moskova yakınlarına gelmiş durumdadır. Bu durumda cepheye gidecek her türlü yardım ve destek şartların zor olması açısından önem kazanmıştır. $\mathrm{Bu}$ fillm savaş sonrası insanlara moral verir. Savaş sırasında bile demiryolu inşaatı devam ederken insanların güç birliğini yaratmaya çalışır. Bayan erkek ayırt etmeden cepheye gidemeyen herkes sabahtan gece yarısına kadar çalışır. Ellerinde teknik araçlar olmadan sadece kürek ve kazma ile yamacının üzerinde demiryolu yapmaya çalışırlar.

Moskova'dan etkili bir şekilde yürütülen Sovyet propagandasının hedefi Rusya'yı aşmış Orta Asya'daki Sovyet cumhuriyetlerine kadar ulaşmıştır. Kırgız belgesel sinemasında da propaganda amaçlı birçok belgesel film çekilmiştir. Kırgızistan'ın hala SSCB cumhuriyetinin içindeyken çekilen Boom belgesel filmi propaganda içerikli mesajlarını ve görüntülerini içermektedir.

Toplumcu gerçekçilik resim, roman ve filmlerde politik ideallerin kişileştirildiği erkek ve kadın kahramanlarla dolu bir dünya yaratmıştır. Yorulmak nedir bilmeyen cesur Kızıl Ordu askerleri, çalışkan kul çocukları veya kendini Parti’ye adamış eylemciler kusursuz bir vatandaşın örnek tavır ve davranışlarını sergilemektedir. Marksizm'in geleceğin uyumlu toplumunda bireyin maksimum gelişiminin olanaklı olacağı düşüncesinden hareketle geliştirilmiştir. Bu bireysel 
gelişme, insanlığın uzun süreli ve kolektif emek sonucunda oluşan zihinsel ve fiziksel ilerleyişinin öncülü olacaktır. (Clark, 2004:118-119)

Filmde uzun süreli yani 4 senelik bir çalışma gösterilmiştir. Bu demiryolu inşaatının bitmesi kolektif emek sonucu gerçekleşmiştir. Yorulmak nedir bilmeyen işçiler bu yolu bitirmek için her şeyini feda etmişler. Amaç, gelecek kuşaklara bir iz bırakma ve anlatmadır. Filmde bu yolun zorlukları ve işçilerin kahramanlıkları anlatılarak yeni nesille aktarılmaktadır.

Kır manzarası çekimlerde elektrik direkleri veya gelişimin doğaya karşı kazandığı zaferi simgeleyen trenler hep gösterilmektedir. Artık Kırgızistan'ın SSCB cumhuriyetlerinden biri olarak Sovyet rejimini yaşayacağını yansıtmaktadır. Artık Kırgızistan iki bölgesi arasındaki demiryolu ta Moskova'ya kadar devam etmektedir. $\mathrm{Bu}$ ise Moskova'nın ülkeyi daha kolay denetlemesine olanak yaratmaktadır.

Simge sistemleri içinde efsane önemli ve etkili bir yer tutmaktadır. Her toplumda o toplumu yaratılışı, tarihsel gelişmesi ve doğaüstü ilişkiler hakkındaki çeşitli efsaneler, destanlar, yazılı ve sözlü kaynaklar vardır. Belli bir toplumun üyesi olarak insan bu kültürel mirası öğrenir, muhafaza eder, savunur ve kendinden sonraki kuşaklara aktarır. Efsaneler bilinmeyeni aramaya çalışan ve bilinmeyeni bulmaya çalışan simgeler sistemidir. Bu süreçte anlatma ve eğlendirme, geçerlilik sağlama ve açıklama işlevlerini yerine getirir. Tüm efsanelerin anlatım özelliği ağır basmaktadır. Geçmiş başarılar, büyük zaferler ve önderlerin başarıları hamasi bir şekilde yoğun duygu ile anlatılır ve birey efsane dünyasının içine çekilir. Bireyin ruhsal dünyasını etkileyen her şeyi efsaneler sunmaktadır. Efsanelerin doğayı tanıma ve bilme isteğinden doğması onun açıklayıcı yanıdır. Efsanelerin yeni kuşaklara aktarılması onlara geleneklerini öğretmekle kalmaz aynı zamanda onların geçmişle olan bağlarını canlı tutar ve yeniden kurar. Propaganda açısından en önemli işlevi ise yönetimi kolaylaştırmak olarak vurgulanabilir. Yöneticiler efsanelerden güç alarak, ona dayanarak, ondan güç ve yetki alarak toplumu yönetebilirler. (Akarcalı, 2003:26) Boom belgesel filminde yaşlı adam demiryolu inşaatı ile ilgili hatıralarını dile getirirken destansı bir anlatım üslubu kullanmaktadır. Böyle bir anlatım biçimi izleyiciyi daha çok etkiler. Boom'da anlatılan efsane ise filmin anlatımını güçlendirerek filme dramatik değer katmaktadır. Filmde geçen efsane de bu şekilde ele alınmaktadır. Bir zamanlar yamaç Isık-Göl'ü seviyormuş ve gölün onu ısıtmasını istemiş ama Göl sularını göndermemiş yamaca ve o günden sonra yamaç daha da sertleşmiş. Halkta "Ulan" denilen soğuk rüzgârla gölün tarafına esip durmuş ve kimseyi göle geçirmeyeceğine yemin etmiş. Bütün soğuk ve karın onları durduramadığını, onların çocuklarını düşündüklerini anlatır. Çünkü onların kendi yeminlerinin olduğunu ve o yemini bozmamaları gerektiğini anlatır yaşlı adam. Bu 
efsane kanyonun üzerindeki demiryolunu ne kadar zor mücadelelerle kurduklarını vurgular.

Propaganda simge kullanarak çeşitli duygu, özlem, istek, kızgınlık gibi kavramları aktarır. Bu simgeleri gerçeğe uyup uyumadığı, doğruluğu ve çevre koşulları irdelenemez. Propaganda döneminde o kadar çok simge kullanılır ki bunun hangisinin gerçeği yansıttığını saptamak son derece güçtür. Simgelere her toplum kendi değer yargılarına göre anlam yükler. Bu nedenle geleneksel ve yüz yüze iletişime alışmış toplumlarda, eğitim düzeyi sınırlı bireylerin kitle iletişim araçlarının sunduğu simgeleri anlayabilmeleri ve bu simgelerin etkisi ile tutum değiştirmeleri son derece zordur. (Akarcalı, 2003:23)

Belgesel filmin başlangıcındaki gösterilen fotoğraftaki "Her şey cephe için, her şey zafer için!” sloganı propagandanın simge kullanarak izleyicinin içinde savaşa karşı kızgınlık, zafere ulaşmak için duygularını kabartıyor. Boom'da demiryolu inşaatı bittikten sonra ilk trenin tören meydanına gelirken üzerinde Lenin'in resmi olan bayrağının dalgalanması propagandanın birer simgesidir. $\mathrm{Bu}$ bayrak Sovyetler Birliğinin ortak simgesidir. Bu bayrağa bakarak o dönemin önemli rejimini ve liderini yansitır.

Yönetmen ellerindeki olan inşaat görüntülerin arşivini modern başkent hayatıyla birlikte kurgular. Taşlar altında kalan inşaatçıların gerçek mezarları ile taşların düşmesinin kurmaca sahneleri kurguda zorluklar getirmiştir. Filmdeki canlandırma sahneleri filmin gücünü azaltmıştı. (Aşımov ve Furtiçev, 1979:67)

$\mathrm{Bu}$ belgesel filmde inşaatçıların başlarına taş düşmesini anlatan sahneleri yönetmen filmi dramatikleştirmek için kullanmış. Gerçekten de bu inşaatta birçok işçi ölmüştür. Ama gerçek mezarlar ile yapay sahneler belgesel filminin doğallığını bozmuş. Ham (felsefi anlamda daha gerçek) ve öyküler uydurma olanlarına göre daha etkilidir. Kendiliğinden eylemler (jestler) perdede daha özel bir değere sahiptir.

Kalabalığı tek bir varlık durumuna getirmek için kullanılan müzik öğesi bireyin kitle içinde erimesine ortak bir bilinç yaratılmasına geniş ölçüde yardımcı olur. En gelişmiş bireyler bile kimi müzik tümcelerinin etkisinden güçlükle sıyrılabilirler. Borularla çalınan asker havaları, marşlar, şarkılar, kesik kesik ve düzenli bir biçimde haykırmalar, kısacası tüm bu "sesli zehirler" kalabalığa taşkınlık vermek için kullanılan ilaçlardır. (Domenach, 2003:74)

Boom belgesel filminde kullanilan müzik her zaman bayramlarda toplu yürüyüş sırasında çalınan marştır. $\mathrm{Bu}$ marşı dinleyen izleyici kendini yalnız hissetmez. Bir kitleye ait olduğuna inanır. Mutluluk hissi artar. Filmin en sonunda 
da bu tarz marşın kullanılması bir zaferin simgesidir. Çünkü Sovyetler Birliği Almanya'yı yeniyor ve demiryolunun inşaatı da başarıyla tamamlanıyor.

\section{Sonuç ve Tartışma}

Bütün kitle iletişim araçlarının içinden propaganda adına en önemlilerinden birisi olarak sinema sanatı karşımıza çıkmaktadır. M. McLuhan sinemayı "sıcak" kitle iletişim araçlarından biri olduğunu söylemektedir. Başka bir deyişle izleyicinin algılama sürecini tamamen ele geçirerek izleyicinin filmin kahramanlarıyla, bazen de kameranın kendisiyle özdeşleşmesini sağlıyor. Karanlık bir salonda, tek bir 1şık kaynağından yansıtılan filmle, insanlar üzerine yaratılan etki çok önemlidir. Bu yüzden Hitler ve Lenin sinemadan sonuna kadar yararlanmaya çalışmıştır.

Sinema, sihir hayallerine kendilerini kaptıran izleyicileri bir araya getirerek milyonlarca insanın duyguları, tutkuları, hüzünleri ve kederleri paylaşmasına olanaklar yaratabilen bir sanat dalıdır. Sadece gerçeği kopyalayan hareket eden fotoğraftan ziyade toplu üretim ve tüketim ürünü olan sinema günlük hayat alışkanlıklarımızı ve geleneklerimizi büyük kitlelere kolayca ulaştırabiliyor.

Kırgız belgesel sinemasının ana teması çağdaşlık, sosyalizm ve komünizm kurucusunun yaratıcı emeği idi. Onun başkahramanı, komünist ruha sahip yeni insan işçi karakteriydi.

Kırgız belgesel sinemasının gelişme sürecinde Kırgı̇ sinemasının öncüllerinden biri olan Tölömüş Okeyev'in Boom adlı belgesel filmi propaganda boyutunu ortaya koymak adına incelenmiştir. Bu bağlamda da Boom belgesel filmi tarihsel eleştirisi açısından ele alındığında; propaganda örnekleri taşıdığı sonuca ulaşılmıştır. $\mathrm{Bu}$ sonuca ulaşırken filmdeki semboller, verilen mesajlar, filmin destansı anlatım şekli belirleyici olmuştur. Demiryolu inşaatçılarını kahramanlaştırarak yeni nesillere miras olarak anlatılan bu film propaganda sembollerini ve mesajlarını içerdiği ortaya konuldu. Bu propaganda sembolleri kamera açıları ve çekim ölçekleri ile güçlendirilmiştir. Bu belgesel filmden hareketle varılan sonuca göre Kırgız belgesel sinemasında Sovyet sinemasının etkisi büyüktür. Çünkü Kırgız belgesel sineması da başka Sovyet cumhuriyetleri gibi Batı'da genel Sovyet Belgesel Sinema olarak kabul edilirdi. Sosyalist cumhuriyetlerinin stüdyolarında, kendi yaşamlarına ait çekilen her film, kendi dilinde yapılsa da mutlaka (öykü, senaryo ve çekilen sahneler) Moskova'da tasdik edilmeliydi. Bu da Kırgız belgesel sinemanın kendi başına özgür hareket edememesine yol açmıştı. Çekilecek tüm filmler sııı bir şekilde denetimden geçmekteydi. 
$\mathrm{Bu}$ da Sovyetler Birliği’nin anlayışına ters düşen filmlerin çekilme olasılığının az olması anlamına gelir. Bu yüzden Sovyetler Birliğini öven ve Sovyet politikasını yansıtan belgesel filmler çekilmek zorundaydı. Günümüzde çekilen belgesel filmlerin çoğunun konusu bağımsızlıktan sonraki ortaya çıkan problemleri içermektedir.

Boom belgesel filmin ana konusunu oluşturan Kant-Rıbaçye demiryolu inşaatı çok önemli bir konudur. Çünkü II. Dünya savaşı sırasında inşaatı başlayan bu demiryolu üzerinden cephe için her türlü yardım ve ihtiyaç gönderilecekti. Savaş sırasında kurulan bu demiryolu hem tarihi hem siyasi açıdan ele alındığında büyük bir önem taşımaktadır. Tarihsel açıdan bakıldığında tren doğaya karşı zaferi simgelemektedir. Siyasi açıdan ise Kırgız Cumhuriyeti'nin Sovyetler Birliğinin başkenti olan Moskova'ya daha da yakınlaştırmıştı. Artık ortadan mesafeler kalkarak ulaşım biçimi kolaylaşmıştı.

Devlet tarafindan Kırgız belgesel sinemasını oluşturmak adına gerekli çalışmalar yapılmamaktadır. Kendi ideolojisini yaymak adına sinemayı sistematik olarak kullanamadığı saptaması yapılmıştır. Kırgız belgesel sinemasının gelişimi ve geldiği nokta bütün sinema dönemleriyle beraber değerlendirildiğinde içinden geçtikleri o siyasi ortamlardan etkilenmiştir.

Kırgız belgesel sinemanın gelişmesi ve dağıtımın olumlu yönde devam etmesi için devletin sinema ile işbirliği yaparak onu hukuki açıdan koruması gerekmektedir. Günümüzde belgesel sinema sanatçılarının en önemli görevi sadece fikri meşgul etmeden hayatın gerçeklerini tüm çıplaklığıyla izleyicilere aktararak toplumsal sorunların çözülmesine yardımcı olması gerekmektedir.

Eskiden Kırgız belgesel sinema Sovyet iktidar ve politikasını yansıtmıştır. Günümüzde ise genel özel kişilerin, sponsorların hareketine göre devam etmektedir. Güç ve iktidar sahibi olan ABD ve batılı ülkeler kendi paket programlarını ve filmlerini üçüncü dünya ülkelerine satarak bundan hem para kazanmakta hem de kendi yaşam biçimlerini, değer yargılarını be kültürlerini bu ülkelere ulaştırmayı başarmış olmaktadır. Bu kültürel erozyondan kaçışı olarak ülkeler kendi ulusal kanallarını ön plana çıkaramaya çalışsalar da bu mesaj bombardımanından kurtulması zor görünmektedir. 


\section{KAYNAKÇA}

Akarcalı, Sezer, 2. Dünya Savaşında İletişim ve Propaganda, İmaj Yayıncılık, Ankara 2003.

Aşimov, Karman, FURTIÇEV, Vilitariy, Kino Sovetskoy Kirgizii, (Sovyet Kırgızistan Sinemas1), İskusstvo Yayınevi, Moskova, 1979.

Baygalieva, Aliya, Sovyet Sineması ve Çok Uluslu Sovyet Sinemasından Bir Yönetmen Tölömüş Okeyev, İstanbul Üniversitesi, Y.L Tezi, 2003.

Brown, Jar, Beyin Yıkama, çev. Behzat Tanç, Boğaziçi Yayınları, 2000.

Domenach, Jean-Marie, Politika ve Propaganda, Varlık Yayınları, İstanbul 2003. 2003.

Öngören, Gündeş, Simten, Film Olgusu: Kuram ve Uygulayım Yaklaşımları, İnkilap,

Mutlu, Erol, İletişim Sözlüğü, Ark Yayınevi, Ankara,1995.

Toby, Clark, Sanat ve Propaganda: Kitle Kültürü Çağında Politik İmge, Ayrıntı Yayınlar1, 2004.

“Dokumentalnie Filmı”, (Çevrimiçi)

http://www.welcome.kg/ru/kyrgyzstan/culture/ggogg/, 15 Kasım, 2007

B.A. Tomman, M.İ.Meltyuhov, D.V. İvanov, “SSSC'nin Devlet Savunma Komitesinin (1941-1945 yy.) Gizli Evraklarının Listesi” (Çevrimiçi) http://www.rusarchives.ru/secret/943.shtml, 7 Mayis, 2007

B.S.Birger, “Josef Şmuleviç BRZOZOWICZ’in İletisi” 16.04.1991, Krasnoyarsk, "Memorial"Kurumu, (Çevrimiçi) http://www.memorial.krsk.ru/svidet/mbrzoz.htm, 12 Mart, 2007

$\begin{array}{lllll}\text { (“Jeleznniye } & \text { Dorogii } & \text { Rosii” } & 7 & \text { Mart }\end{array}$ http://www.1520mm.ru/history/rall50/10.htm ) 